УДК 666.97:543.573

E.N. Polonina,

graduate student

ORCID: 0000-0003-1996-8065

S.N. Leonovich,

doct. tech. sciences, professor

ORCID 0000-0002-4026-820X

Belarusian national technical university

\title{
STUDIES OF STRUCTURAL-PHASE CHANGES IN A MODIFIED CEMENT STONE METHOD BY DERIVATOGRAPHIC ANALYSIS
}

The use of a complex nanodispersed additive consisting of a superplasticizer and nanoparticles (sol of nanosilica and carbon nanomaterial) have a significant effect on the hydration, hardening, and curing of building composites, predetermining their durability.

The results of studies of phase transformations occurring in a cement stone modified with this additive are presented. The studies were carried out using the method of thermal analysis, which allows to obtain quantitative information about the change in the mass of the sample as a result of its heating and at the same time register this change. Thermal analysis has a number of advantages over other research methods, the flexibility of setting up an experiment, the rapid removal of information, the ability to automate data processing, and a small amount of substance. A comprehensive study of the properties of a material when it is heated allows a detailed and deeper study of the nature of the processes occurring in it. The study of physical and chemical processes was carried out on a combined thermogravimetric analysis device and differential scanning calorimetry METTLER TOLEDO, which is designed to measure the thermodynamic characteristics (heat and temperature of phase transitions and physicochemical reactions), as well as detect changes in the mass of materials in the temperature range from 25 to 1600 degrees $C$. The article discusses the intervals of weight loss of samples containing an additive of superplasticizer and a complex nanodispersed additive in age those 1 and 28 days. To find out what effect a superplasticizer has on a cement sample, an additional sample No. 1, consisting only of cement and water, was examined at 28 days of age.

Key words: complex nanodispersed additive, nanosilica sol, carbon nanomaterial, thermodynamic characteristics, experimental studies.

Formulation of the problem. Concrete is one of the fire resistant materials. Due to the relatively low thermal conductivity, the short-term effect of high temperatures does not significantly affect its properties. But with an increase in the degree and duration of heating in concrete, irreversible changes occur [1]

Concrete structures in case of fire are exposed to high temperatures - from $800^{\circ} \mathrm{C}$ and above, which subsequently leads to a decrease in the bearing capacity of concrete and reinforced concrete structures and further to their complete destruction.

Analysis of research and publications, statement of the problem. The method of derivatographic analysis is aimed at fixing the physicochemical properties of a substance in the process of temperature effects [2-7]. The aim of the study is to study the effect of 
a complex nanodispersed additive consisting of a superplasticizer and nanoparticles (sol of nanosilica and carbon nanomaterial) on the properties of the cement material.

\section{Research Methods.}

Prototypes.

Structural-phase changes in hardened cement stone were studied on samples of the following samples:

No. 1 - control sample (cement-water),

No. 2 - sample containing the addition of superplasticizer (SP),

No. 5 sample containing a complex additive consisting of a superplasticizer and nanoparticles of nanoparticles (sol of nanosilica and carbon nanomaterial) [8-10].

The additive in samples No. 1,2 and 5 was introduced in an amount of $0.8 \%$ by weight of cement. The amount of mixing water for all samples was selected in such a way as to obtain a dough of normal density in all cases. Samples of beams with dimensions of 40x40x160 mm were made from cement paste of normal density. Tests were conducted at the age of 1 and 28 days.

Methodology for sample preparation.

The preparation consists in removing water from the pores and micropores so that the cement hydration reactions do not continue further. It is impossible to simply dry the sample to remove pore water in an oven at $105^{\circ} \mathrm{C}$, because together with the pore water, the sample will lose part of the hydrated water, which has already reacted with cement minerals and has become fixed in calcium silicate hydrates. After drying at $105^{\circ}$ $\mathrm{C}$ we obtain, according to the data, an underestimated content of hydrated water and, accordingly, an underestimated content of calcium silicate hydrates. Therefore, drying was carried out in acetone at $50-60^{\circ} \mathrm{C}$. Acetone is able to chemically bind water and evaporate at $50-60{ }^{\circ} \mathrm{C}$, taking away pore water with it, and at the same time crystallization hydrated water is not affected, which is fixed in hydrates of calcium silicates. Without acetone, it would be impossible to remove pore water without destroying calcium silicate hydrates.

The procedure was as follows: a) crushing the sample, b) abrasion to powder, c) adhering acetone to the powder, d) drying in a drying oven at $50-60^{\circ} \mathrm{C}$ in acetone for 30 minutes. If acetone completely evaporated earlier than after 30 minutes, then it was added additionally.

The equipment used.

The study of the physicochemical processes occurring during the high-temperature heating of cement stone samples was carried out using a combined thermogravimetric analysis and differential scanning calorimetry METTLER TOLEDO (Switzerland). This device is intended for measuring thermodynamic characteristics (heat and temperature of phase transitions and physicochemical reactions), as well as recording changes in the mass of solid and powder materials in the temperature range from 25 to 1600 degrees $\mathrm{C}$.

Thermogravimetric analysis (TGA) allows you to obtain quantitative information about the change in mass of a sample as a result of heating, cooling, exposure at a constant temperature in accordance with a given temperature program and in a specific gas atmosphere.

Thanks to the unique design of the thermal sensors integrated in the measuring cell, the TGA / DSC1 also enables differential scanning calorimetry (DSC). Such a constructive solution makes it possible to carry out measurements of calorimetric quantities at different thermodynamic transitions accompanied by a change in the mass of the test sample at the same time in one experiment and on the same sample, and 
record this change. The device is made in the form of a single desktop measuring module, consisting of a temperature unit (furnace), a unit for measuring mass change (scales), a calorimetric sensor - a sample holder, placed in a furnace with adjustable temperature and heating speed, an electronic control and measurement unit.

The principle of measuring the amount of heat released or absorbed by the sample is based on the integration of a sensor signal over time that measures the difference in heat fluxes between two cups, one of which is filled with a sample, while being simultaneously controlled by the speed of heating in the furnace to a predetermined temperature controlled by the sensor.

The principle of operation of the scales is based on compensation for changes in the weight of the sample by electromagnetic force created by the automatic balancing system. The measuring unit of the balance is thermostatically controlled by an external circulation thermostat.

\section{Main part.}

Figures 1-5 show diagrams of samples of cement stone at the age of 1 and 28 days.

Three main intervals are considered (Figure 1.2):

1 interval. From $20-30^{\circ} \mathrm{C}$ to $300^{\circ} \mathrm{C}$. The mass loss in this interval refers to hydrated water $\mathrm{H} 2 \mathrm{O}$, which was bound in the hydration reactions of alite and other clinker minerals, and transferred to the composition of calcium hydrosilicates and hydrates of calcium-aluminate and calcium-aluminoferrite. In this interval, there are minima on the DTG and DSC curves corresponding to the maximum rate of hydrated water removal. If we take the interval of $30-300{ }^{\circ} \mathrm{C}$, then sample No. 2 lost $7.6 \%$ of its mass in this interval, sample No. 5 is less $-7.06 \%$. The relative difference in this case is $7.6 / 7.06=$ $1.076=7.6 \%$. This difference is in favor of sample No. 2 without nanoparticles.

If the entire 1st and 2nd interval, as highlighted in the graphs, from 30 to $425^{\circ} \mathrm{C}$ are attributed to losses of hydrated water, then sample No. 2 lost $8.27 \%$ of the mass, sample No. $5-7.72 \%$, i.e. $7.1 \%$ less $(8.27 / 7.72=1.071)$. It turns out that the proportion of hydrated water is again larger in sample No. 2 .

2 interval. From 450 to $550^{\circ} \mathrm{C}$. In this range, weight loss is attributed to decomposition of Portlandite $\mathrm{Ca}(\mathrm{OH}) 2$ into $\mathrm{CaO}$ and $\mathrm{H} 2 \mathrm{O}$ upon heating. Portlandite is formed as a result of hydration of alite and belite. On the graphs, the interval $425-491^{\circ} \mathrm{C}$ is highlighted. In this interval, respectively, there are sharp minima on the DTG and DSC curves, confirming the decomposition of portlandite.

Sample No. 2 lost in this interval $425-491^{\circ} \mathrm{C} 1.59 \%$ of the mass, sample No. 5 $1.48 \%$ of the mass. It turns out that in sample No. 2 the hydrated water associated with portlandite is relatively larger by $1.59 / 1.48=1.074=7.4 \%$.

3 interval. This range corresponds to the decomposition of calcium carbonate $\mathrm{CaCO} 3$ into $\mathrm{CaO}$ and carbon dioxide $\mathrm{CO} 2$. The formation of calcium carbonate in cement stone is wholly attributed to the continuous carbonization of portlandite due to contact with carbon dioxide gas. Typically, calcium carbonate decomposes in the range of $780-820^{\circ} \mathrm{C}$ with corresponding sharp minima on the DTG and DSC curves. On the charts, these minima fall on the interval $540-800^{\circ} \mathrm{C}$. For sample No. 2 in this interval, the mass loss is $2.438 \%$, for sample No. $5-2.709 \%$. If the losses are multiplied by the ratio of the molar masses of $\mathrm{H} 2 \mathrm{O}$ and $\mathrm{CO} 2-18 / 44=0.409$, then we get the equivalent loss of water by portlandite. In the range of $540-800^{\circ} \mathrm{C}$ for sample No. $2-0.9971 \%$, for sample No. $5-1.1079 \%$. The relative difference is $1.1079 / 0.9971=1.111=11.1 \%$ in favor of sample No. 5 . 


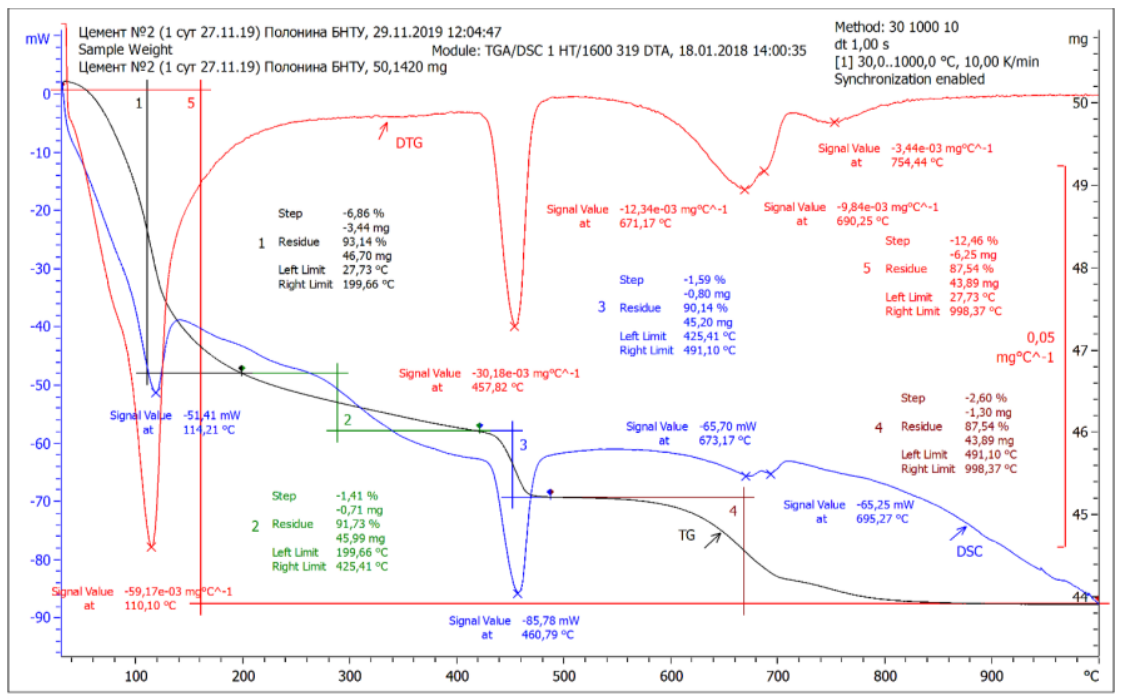

Lab: METTLER

STAR $^{\text {e }}$ SW 14.00

Fig. 1 - TG measurement results of cement sample No. 2 at the age of 1 day

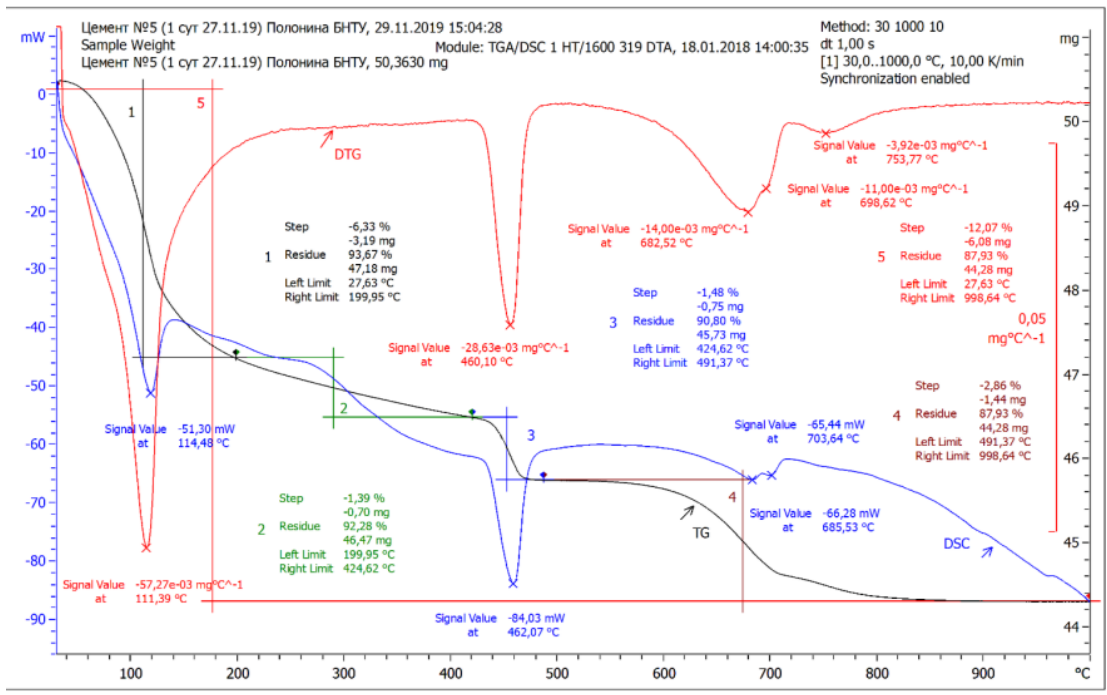

Lab: METTLER

STAR $^{\mathrm{e}} \mathrm{SW} 14.00$

Fig. 2 - TG measurement results of cement sample No. 5 at the age of 1 day 
The total water associated with portlandite, by the sum for intervals 2 and 3 for sample No. 2, was $1.59+0.9971=2.5871 \%$, for sample No. $5,1.48+1.1079=$ $2.5879 \%$. The relative difference is $0.03 \%$. Those. the amount of water associated with portlandite, and the amount of portlandite itself, formed during the hydration of alite and belite, are the same.

If we attribute the amount of water released in the 1st interval, when hydrates are decomposed, to the total amount of water corresponding to the 2 nd and 3rd intervals portlandite decomposition, then for sample No. 2 it is $7.6 / 2.5871=2.937$, for sample No. $5-7.06 / 2.5879=2.728$, which corresponds to stoichiometry of the alite hydration reaction. The relative differences in interval losses at the level of tenths of a percent are negligible.

It turns out that hydration water, judging by the 1st interval, is larger in sample No. 2. The amount of portlandite in the samples is approximately the same.

The difference in hydrated water between samples No. 2 and No. 5 at the age of 1 day is not so significant as to make a confident conclusion about faster hydration in one of the samples. It is worth noting that the total mass loss in samples No. 2 and 5 in the range of $30-1000^{\circ} \mathrm{C}$ differ even less $-12.46 \%$ and $12.07 \%$, i.e. only $12.46 / 12.07=$ $1.032=3.2 \%$.

Comparison at the age of 28 days was carried out between samples of samples No. 2 and No. 5. In order to find out what effect the superplasticizer has, sample No. 1 was additionally investigated.

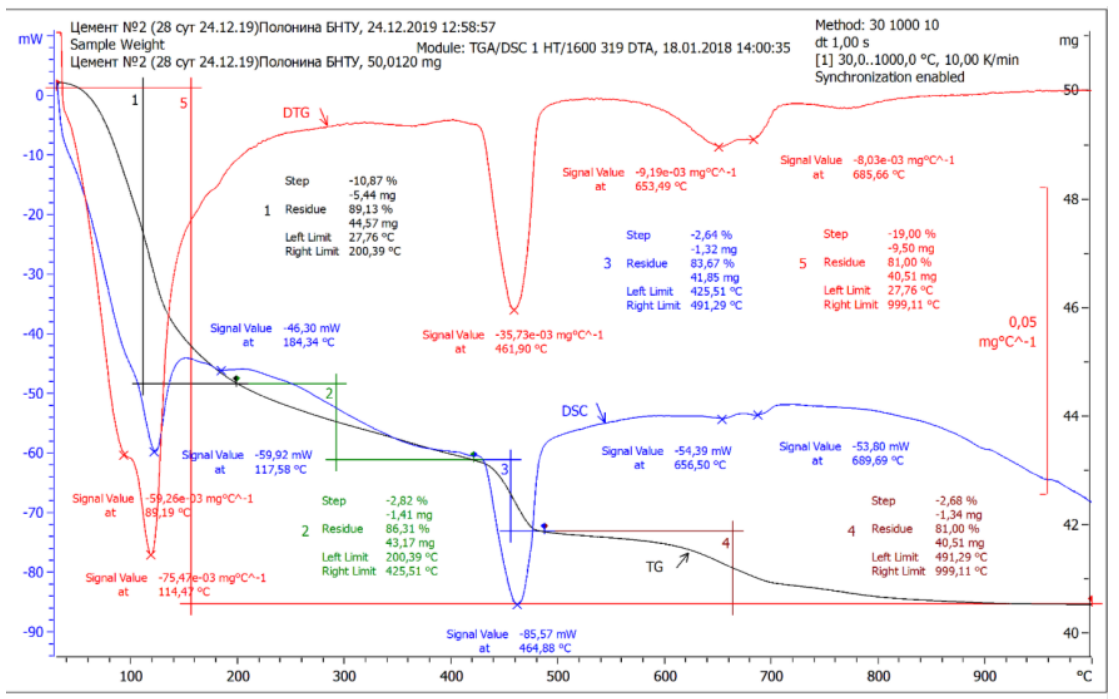

Lab: METTLER

STAR $^{\mathrm{e}}$ SW 14.00

Fig. 3 - TG results of measuring a sample of cement sample No. 2 at the age of 28 days 


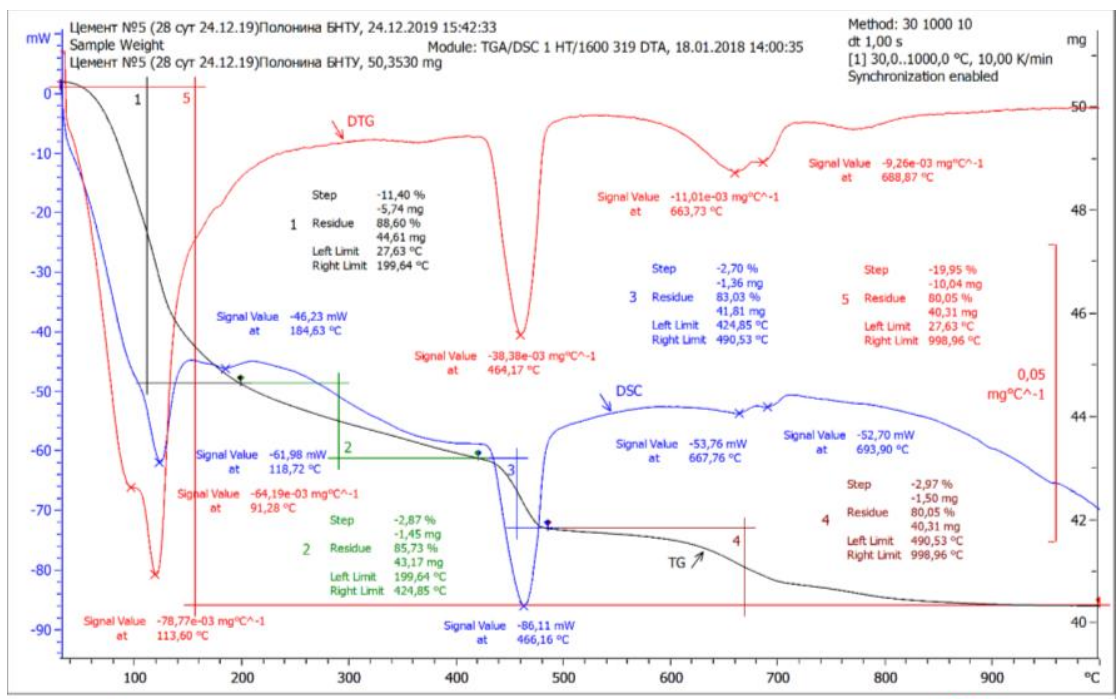

Lab: METTLER

STAR $^{\mathrm{e}} \mathrm{SW} 14.00$

Fig. 4 - TG results of measuring cement sample No. 5 at the age of 28 days

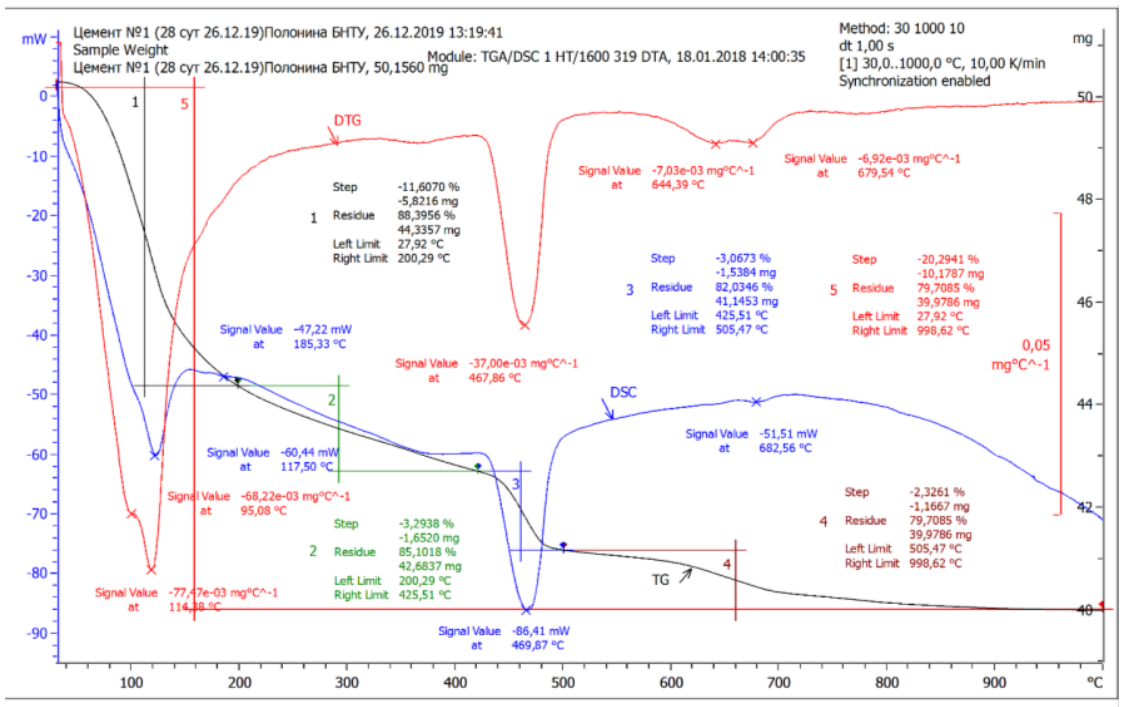

Lab: METTLER

STAR $^{\mathrm{e}}$ SW 14.00

Fig. 5 -TG results of measuring a sample of cement sample No. 1 at the age of 28 days 

$3,4,5)$ :

We examined 3 intervals of weight loss at the age of 28 days on the TG-curve (Fig.

1 interval. In the range of $30-300^{\circ} \mathrm{C}$, sample No. 1 lost $13.29 \%$ of its mass, sample No. 2 - $12.31 \%$, sample No. $5--12.9 \%$. The relative difference is $13.29 / 12.9=1.030=$ $3 \%$ (sample No. 1). The difference is $12.9 / 12.31=1.048=4.8 \%$ for sample No. 5 containing nanoparticles and a super-plasticizer, compared with a sample modified only with a superplasticizer.

If the entire 1st and 2nd interval, as highlighted in the graphs, is from 30 to $425^{\circ} \mathrm{C}$, the loss of hydrated water includes sample No. 1 lost $14.90 \%$ of the mass, No. 2 $13.69 \%$ of the mass, sample No. $5-14.27 \%$, i.e. sample No. 5 lost hydrate water by $4.2 \%$ more than sample No. $2(14.27 / 13.69=1.042)$, but $4.4 \%$ less than sample No. 1 $(14.9 / 14.27=1.044)$.

Thus, the proportion of hydrated water is greater in sample No. 1. But if we compare sample No. 2 with sample No. 5, then the hydration water is greater in sample No. 5.

2 interval. Sample No. 1 lost in this interval - 3.07\% of the mass, sample No. 2 $2.64 \%$, sample No. $5-2.7 \%$ of the mass. In sample No. 1, the hydration water associated with Portlandite is relatively $3.07 / 2.7=1.137=13.7 \%$ more than in sample No. 5. But if we compare sample No. 2, then the hydration water in it is less than in sample No. 5 by $2.7 / 2.64=1.023=2.3 \%$.

3 interval. For sample No. 1, the mass difference (41.1793-40.1268) / 50.1573 was $0.021=2.1 \%$, for sample No. $2-2.35 \%$, for sample No. $5-2.61 \%$.

If these losses are multiplied by the molar mass ratio, then the equivalent loss of water by portlandite in the range of $500-800^{\circ} \mathrm{C}$ for sample No. 1 is $0.859 \%$, for sample No. $2-0.961 \%$, for sample No. $5-1.068 \%$. The relative difference is $1.068 / 0.859=$ $1.243=24.3 \%$ in favor of sample No. 5 compared to sample No. 1 and $11.1 \%(1.068 /$ $0.961=1.111$ ) compared to sample No. 2 .

The total water associated with portlandite, in the sum for intervals 2 and 3 for sample No. $1-3.07+0.859=3.929 \%$, for sample No. $2-2.64+0.961=3.601 \%$, for sample No. $5-2.7+1.068=3.768 \%$, i.e. water associated with portlandite, in sample No. 5 more than in No. 2 by $3.768 / 3.601=1.046=4.6 \%$, but less by $3.929 / 3.768=$ $1.043=4.3 \%$ than sample No. 1 .

\section{Conclusions:}

1) In the method of thermogravimetry itself there is an inaccuracy associated with the choice of the boundaries of the intervals. For example, if the first interval is chosen within $30-300 \mathrm{C}$, then in sample 1 , the mass loss is $13.29 \%$. If the first interval is chosen within the range of $30-425 \mathrm{C}$, then the mass loss is $14.90 \%$, i.e. relative change 14.9 / $13.29=1.12=12 \%$.

2) Sample No. 1 has a mass loss greater than sample No. 2 in the 1 st interval by $7.96 \%$. In sample No. 2 modified with a superplasticizer, SP slowed down the hydration of cement.

3) The mass loss in sample No. 1 is greater than in No. 5.

4) Sample No. 5 at the age of 1 day showed a lower weight loss compared to sample No. 2, and at the age of 28 days a large weight loss (about 5\%).

5) The difference of $5 \%$ between samples No. 5 and No. 2 is negligible.

6) Experimental studies of modified cement samples by the method of derivatographic analysis are ongoing. 


\section{References}

1. Plotnikova G.V., Dashko L.V., Klyuchnikov V.Yu., Sinyuk V. D. (2015). Primeneniye metodov termicheskogo analiza pri issledovanii tsementnogo kamnya. Vestnik Vostochno-Sibirskogo instituta MVD Rossii. №2 (73).

2. Ayupov, D.A., Fakhrutdinova, V.Kh. Makarov, D.B (2018).Fiziko-khimicheskiye metody issledovaniya stroitel'nykh materialov. Instrumental'nyy analiz: uchebnoye posobiye. Kazan': Izd-vo Kazansk. Gos. arkhitekt.-stroit. un-ta. 166p.

3. Semerikov, I.S., Gerasimova, Ye.S. (2015). Fizicheskaya khimiya stroitel'nykh materialov: ucheb. posobiye. Yekaterinburg: Izd-vo Ural. un-ta. 204p.

4. Galkin, Yu.Yu., Udodov, S.A. (2017). Izucheniye poteri massy tsementnykh sistem pri szhatii. Inzhenernyy vestnik Dona. №. 1 (44). pp. 103.

5. Shoshin, Ye.A., Polyakov, A.V., Bylinkina, N.N., Burov, A.M. (2016). Mikroskopicheskoye issledo-vaniye produktov termicheskoy degidratatsii modifitsirovannykh tsementnykh gidrosilika-tov. Vestnik Belgorodskogo gosudarstvennogo tekhnologicheskogo universiteta im. V.G. Shukhova. № 1, pp. 18-25.

6. Khuzin, A.F. (2016). Kinetika teplovydeleniya pri gidratatsii tsementa, modifitsirovannogo kompleksnoy nanomodifitsirovannoy dobavkoy. Izvestiya Kazanskogo gosudarstvennogo arkhitekturno-stroitel'nogo universiteta. № 1 (35), pp. 216-220.

7. Kopanitsa, N.O., Sarkisov, Yu.S., Dem'yanenko, O.V. (2016). Primeneniye nanodispersnogo kremnezema v proizvodstve stroitel'nykh smesey. Vestnik Tomskogo gosudarstvennogo arkhitekturno-stroitel'nogo universiteta. № 5 (58), pp. 140-150.

8.Potapov, V.V., Gorev, D.S. (2018). Fiziko-khimicheskiye kharakteristiki nanokremnezema (zol', nanoporoshok) i mikrokremnezema. Fundamental'nyye issledovaniya. №. 6. pp. 23-29.

9. Zhdanok, S.A., Polonina, Ye.N., Leonovich, S.N., Khrustalev, B.M., Koleda, Ye.A. (2019). Fiziko-mekhanicheskiye kharakteristiki betona, modifitsirovannoy plastifitsiruyushchey dobavkoy na osnove nanostrukturirovannogo ugleroda. Inzhenernofizicheskiy zhurnal. Tom 92, №1 (yanvar'-fevral'). pp.14-20.

10. Zhdanok, S.A., Polonina, Ye.N., Leonovich, S.N., Khrustalev, B.M., Koleda, Ye.A. (2019). Vliyaniye plastifitsiruyushchey dobavki na osnove nanostrukturirovannogo ugleroda $\mathrm{v}$ samouplotnyayushchiyesya smesi $\mathrm{s}$ yeye tekhnologicheskimi svoystvami. Inzhenerno-fizicheskiy zhurnal. Tom 92, №2 (mart-aprel'). pp.391-396.

\section{Список литературы:}

1. Плотникова Г. В., Дашко Л. В., Ключников В. Ю., Синюк В. Д. Применение методов термического анализа при исследовании цементного камня // Вестник Восточно-Сибирского института МВД России. 2015. №2 (73).

2. Физико-химические методы исследования строительных материалов. Инструментальный анализ: учебное пособие / Д.А. Аюпов, В.Х. Фахрутдинова, Д.Б. Макаров. - Казань: Изд-во Казанск. Гос. архитект.-строит. ун-та, 2018. - 166 с

3. Семериков И.С. Физическая химия строительных материалов: учеб. пособие / И.С. Семериков Е.С. Герасимовой. - Екатеринбург: Изд-во Урал. ун-та, 2015. - 204 с.

4. Галкин Ю.Ю., Удодов С.А. Изучение потери массы цементных систем при сжатии // Инженерный вестник Дона, 2017. №. 1 (44). - С. 103.

5. Шошин Е.А., Поляков А.В., Былинкина Н.Н., Буров А.М. Микроскопическое исследование продуктов термической дегидратации модифицированных цементных гидросиликатов // Вестник Белгородского государственного технологического университета им. В.Г. Шухова, 2016, № 1, с. 18-25. 
6. Хузин А.Ф. Кинетика тепловыделения при гидратации цемента, модифицированного комплексной наномодифицированной добавкой // Известия Казанского государственного архитектурно-строительного университета, 2016. № 1 (35). 216-220.

7. Копаница Н.О., Саркисов Ю.С., Демьяненко О.В. Применение нанодисперсного кремнезема в производстве строительных смесей // Вестник Томского государственного архитектурно-строительного университета, 2016. № 5 (58), c. 140-150.

8. Потапов В.В. Физико-химические характеристики нанокремнезема (золь, нанопорошок) и микрокремнезема / В.В. Потапов, Д.С. Горев // Фундаментальные исследования. - 2018. - № 6. - С. 23-29.

9. Жданок С.А., Полонина Е.Н., Леонович С.Н., Хрусталев Б.М., Коледа Е.А. Физико-механические характеристики бетона, модифицированного пластифицирующей добавкой на основе наноструктурированного углерода // Инженерно-физический журнал. 2019. Том 92, №1 (январ-февраль). С.14-20.

10. Жданок С.А., Полонина Е.Н., Леонович С.Н., Хрусталев Б.М., Коледа Е.А. Влияние пластифицирующей добавки на основе наноструктурированного углерода в самоуплотняющейся бетонной смеси на ее технологические свойства // Инженернофизический журнал. 2019. Том 92, №2 (март-апрель). С.391-396.

\section{Е.Н. Полонина, С.Н. Леонович}

Исследования структурно-фазовых изменений в модифицированном цементном камне методом дериватографического анализа

Использование комплексной нанодисперсной добавки, состоящей из суперпластификатора и наночастич (золя нанокремнезема и углеродного наноматериала) имеют значительное влияние на процессы гидратации, твердения, набора прочности строчтельных композитов, предопределяя их долговечность.

Приведены результаты исследований фазовых превращений, происходящих в иементном камне, модифицированного данной добавкой. Исследования проведень c помощью метода термического анализа, который позволяет получить количественную информацию об изменении массы образияа в результате его нагревания и при этом регистрировать это изменение. Термический анализ имеет ряд преимуществ перед другими методами исследований, гибкость постановки эксперимента, быстрое снятие информации, возможность автоматизации при обработке данных, малое количество вещуества. Комплексное изучение свойств материала при его нагревании позволяет детально и более глубоко исследовать природу протекающих в нем процессов. Исследование физико-химических процессов, проводилось на устройстве совмещенного термогравиметрического анализа и дифференииальной сканирующей калориметрии METTLER TOLEDO, который предназначен для измерения термодинамических характеристик (теплоты $u$ температуры фазовых переходов и физико-химических реакиий), а также регистрации изменения массы материалов в диапазоне температур от 25 до 1600 градусов C. В статье рассмотрены интерваль потери массы образиов, содержащую добавку суперпластификатора и комплексную нанодисперсную добавку в возрасте 1 и 28 
суток. Чтобы выяснить какое влияние оказывает суперпластификатор на цементный образец, дополнительно в 28 суточном возрасте был исследован образеи №1, состоящий только из цемента и водыл.

Ключевые слова: комплексная нанодисперсная добавка, золь нанокремнезема, углеродный наноматериал, термодинамические характеристики, экспериментальные исследования.

\section{Е.Н. Полонина, С.Н. Леонович}

Дослідження структурно-фазових змін в модифікованому цементному камені методом деріватографіческого аналізу

Використання комплексної нанодисперсному добавки, щзо складається 3 суперпластифікатора $i$ наночастинок (золю нанокремнезема $i$ вуглецевого наноматериал) мають значний вплив на процеси гідратації, твердіння, набору мічності будівельних композитів, зумовлюючи їх довговічність.

Наведено результати досліджень фазових перетворень, щуо відбуваються в иементному камені, модифікованого даної добавкою. Дослідження проведені за допомогою методу термічного аналізу, який дозволяе отримати кількісну інформацію про зміну маси зразка в результаті його нагрівання $і$ при ияьому реєструвати ичю зміну. Термічний аналіз має ряд переваг перед іншими методами досліджень, гнучкість постановки експерименту, швидке зняття інформації, можливість автоматизації при обробиі даних, мала кількість речовини. Комплексне вивчення властивостей матеріалу при його нагріванні дозволяє детально $і$ більи глибоко дослідити природу протікають в ньому прочесів. Дослідження фізико-хімічних прочесів, проводилося на пристрої суміщеного термогравіметричного аналізу та диференціальної скануючої калориметрії METTLER TOLEDO, який призначений для вимірювання термодинамічних характеристик (теплоти $і$ температури фазових переходів $і$ фізико-хімічних реакиій), а також реєстрації зміни маси матеріалів в діапазоні температур від 25 до 1600 градусів С. у статті розглянуті інтервали втрати маси зразків, щуо містить добавку суперпластифікатора $і$ комплексну нанодисперсному добавку в возра ті 1 i 28 діб. Щоб з'ясувати який вплив надає суперпластифікатор на ичементний зразок, додатково в 28 добовому віцฺі був досліджений зразок №1, щ⿻о складається тільки з иементу і води.

Ключові слова: комплексна нанодисперсному добавка, золь нанокремнезема, вуглецевий наноматериал, термодинамічні характеристики, експериментальні дослідження.

\section{Посилання на статтю}

APA: Polonina, E.N. \& Leonovich, S.N. (2020). Studies of structural-phase changes in a modified cement stone method by derivatographic analysis. Shliakhy pidvyshchennia efektyvnosti budivnytstva v umovakh formuvannia rynkovykh vidnosyn, 43, 32-41.

ДСТУ: Polonina E.N. Studies of structural-phase changes in a modified cement stone method by derivatographic analysis [Текст] / E.N. Polonina, S.N. Leonovich // Шляхи підвищення ефективності будівництва в умовах формування ринкових відносин. 2020. - № 43. - C. 32-41. 